\title{
Heavy Metals Distribution in Soil, Water, Vegetation and Meat in the Regions of East-Kazakhstan
}

\author{
Aitbek Kakimov $^{1}$, Zhainagul Kakimova ${ }^{1}$, Zhanibek Yessimbekov ${ }^{1 *}$, Aigerim Bepeyeva ${ }^{1}$, \\ Klara Zharykbasova ${ }^{2}$, Yerlan Zharykbasov ${ }^{1}$ \\ ${ }^{1}$ Shakarim Semey State University, Semey, Republic of Kazakhstan; ${ }^{2}$ Kazakh Humanitarian Juridical Innovative University, Semey, \\ Republic of Kazakhstan. \\ Email: *ezhanibek@mail.ru
}

Received July $26^{\text {th }}, 2013$; revised August $25^{\text {th }}, 2013$; accepted September $24^{\text {th }}, 2013$

Copyright (c) 2013 Aitbek Kakimov et al. This is an open access article distributed under the Creative Commons Attribution License, which permits unrestricted use, distribution, and reproduction in any medium, provided the original work is properly cited.

\begin{abstract}
In this study, the pollution level of $\mathrm{Cd}, \mathrm{Pb}, \mathrm{Zn}$ and $\mathrm{Cu}$ was estimated in the samples of soil, water, vegetation and milk collected from the regions of East-Kazakhstan. High concentrations in the soils were measured of Cd in Ayaguz 0.11 $\mathrm{mg} / \mathrm{kg}$, of Pb in Urdzhar $19.7 \mathrm{mg} / \mathrm{kg}$, of Zn in Naualy $17.3 \mathrm{mg} / \mathrm{kg}$ and $\mathrm{Cu}$ in Kabanbai $0.21 \mathrm{mg} / \mathrm{kg}$. These measured data did not exceed the National limits for Cd $0.5 \mathrm{mg} / \mathrm{kg}, \mathrm{Pb} 32.0 \mathrm{mg} / \mathrm{kg}, \mathrm{Zn} 23.0 \mathrm{mg} / \mathrm{kg}$ and $\mathrm{Cu} 3.0 \mathrm{mg} / \mathrm{kg}$. The results of the vegetation analysis showed the presence of high levels of Cd in Ayaguz $0.346 \mathrm{mg} / \mathrm{kg}$, which exceeded the National limit $0.2 \mathrm{mg} / \mathrm{kg}$. Considerable quantity of $\mathrm{Pb} 1.96 \mathrm{mg} / \mathrm{kg}$, Zn $20.7 \mathrm{mg} / \mathrm{kg}$, Cu $11.1 \mathrm{mg} / \mathrm{kg}$ was measured in Naualy. In water samples of Urdzhar region $\mathrm{Pb}$ value of $0.039 \mathrm{mg} / \mathrm{dm}^{3}$ was a little higher than the National limit of $0.03 \mathrm{mg} / \mathrm{dm}^{3}$. Zn content in Naualy $1.5 \mathrm{mg} / \mathrm{dm}^{3}$, in Kabanbai $1.25 \mathrm{mg} / \mathrm{dm}^{3}$, in Urdzhar $1.05 \mathrm{mg} / \mathrm{dm}^{3}$ was found to exceed the National limit $1.0 \mathrm{mg} / \mathrm{dm}^{3}$. The level of $\mathrm{Pb}$ in milk samples from Urdzhar $0.39 \mathrm{mg} / \mathrm{kg}$, Naualy $0.24 \mathrm{mg} / \mathrm{kg}$ and Ayaguz $0.15 \mathrm{mg}$ was found to be higher than the National limit $0.1 \mathrm{mg} / \mathrm{kg}$. Zn concentration exceeded the National limit $5.0 \mathrm{mg} / \mathrm{kg}$ in the samples from Kabanbai $6.3 \mathrm{mg} / \mathrm{kg}$ and Naualy $5.8 \mathrm{mg} / \mathrm{kg}$.
\end{abstract}

Keywords: Heavy Metal; Soil; Water; Vegetation; Meat; East-Kazakhstan; ICP-MS

\section{Introduction}

Environmental pollution is one of the most serious problems, which requires urgent practical attention. Environmental pollution whether in solid, liquid or gaseous form is causing adverse effects on the behavior and life of mankind and considerably damaging the animal and plant life [1]. Anthropogenic activities are the major sources of heavy metals redistribution [2]. Heavy metals are the elements having density more than $5 \mathrm{~g} / \mathrm{cm}^{3}$, atomic weight 63.546 to 200.590 and a specific gravity greater than 4.0. Although heavy metals by and large remain in ground water and soil, in certain areas their level increase and they tend to accumulate to toxic levels in human and animal tissues deriving food from water and soils. Living organisms normally require some of these heavy metals up to certain limits, and in case excess accumulation occurs, it will lead to severe detrimental effects [3].

Excess content of cadmium, lead, copper and zinc in

*Corresponding author. the environment, primarily due to the operation of Industrial enterprises, such as machine-building plant (Semey), Cement Plant (Semey), as well as gravel-sand mining enterprises on the Airfield site, rocky soil in Ayagoz region ("Kazakhmys Corporation”), the production of brick loam on the field Urdzharsky-2 ("Urdzharsky PMK-1" Company, Urdzhar), boiler and heating plants, railroads and highways, contaminates adjacent territories. On the other hand, studying heavy metals is especially important in East Kazakhstan, because of nuclear tests that were conducted on the Semipalatinsk Nuclear Test Site (SNTS). SNTS covers a portion of the northwestern part of the East Kazakhstan oblast (formerly known as the Semipalatinsk oblast), as well as parts of the Pavlodar and Karaghandy oblasts (oblasts are administrative units, similar to states in the US) [4]. The soils polluted with heavy metals from the affected zones by the mining and metallurgical industry are strongly degraded (eroded), without vegetation and structure [5]. Foodstuffs grown on contaminated soil or irrigated with impure water accumulate 
metal contents and are a big source of heavy metals exposure to the animals and humans [6].

The aim of this study is to assess the degree of heavy metals contamination in soil, water, vegetation and milk in different regions of East Kazakhstan and provide a very practical heavy metal data set to better evaluate pollution loading and the toxicity status.

\section{Materials and Methods}

Samples of soil, water and vegetation were collected from 10 locations of Abai, Ayagoz and Urdzhar regions (Figure 1). Soil was collected using a special shovel to a depth of $5 \mathrm{~cm}$ (surface to $5 \mathrm{~cm}$ depth). For each grabs, the area sampled was $100 \mathrm{~cm}^{2}$. To make up one sample, soil grabbed from 5 different places within $50 \mathrm{~m}$ perimeter were mixed together in a large container. The soil samples were packed into the special polyethylene sack, labeled and transported to the laboratory.

Vegetation cover of studied area is represented by grass: In Abai and Ayaguz regions Artemísia, Stipa, Festuca valesiaca, Koeléria; In Urdzhar region Filipéndula, Artemísia, Stipa, Festuca valesiaca, Koeléria. The vegetation was stored in a separate room with draught cupboard. Cleaned and dried samples were milled until $1 \mathrm{~cm}$ of size and dried within a temperature $70^{\circ} \mathrm{C}-80^{\circ} \mathrm{C}$ for $15-18$ hours.

Water samples were collected from the surface of the

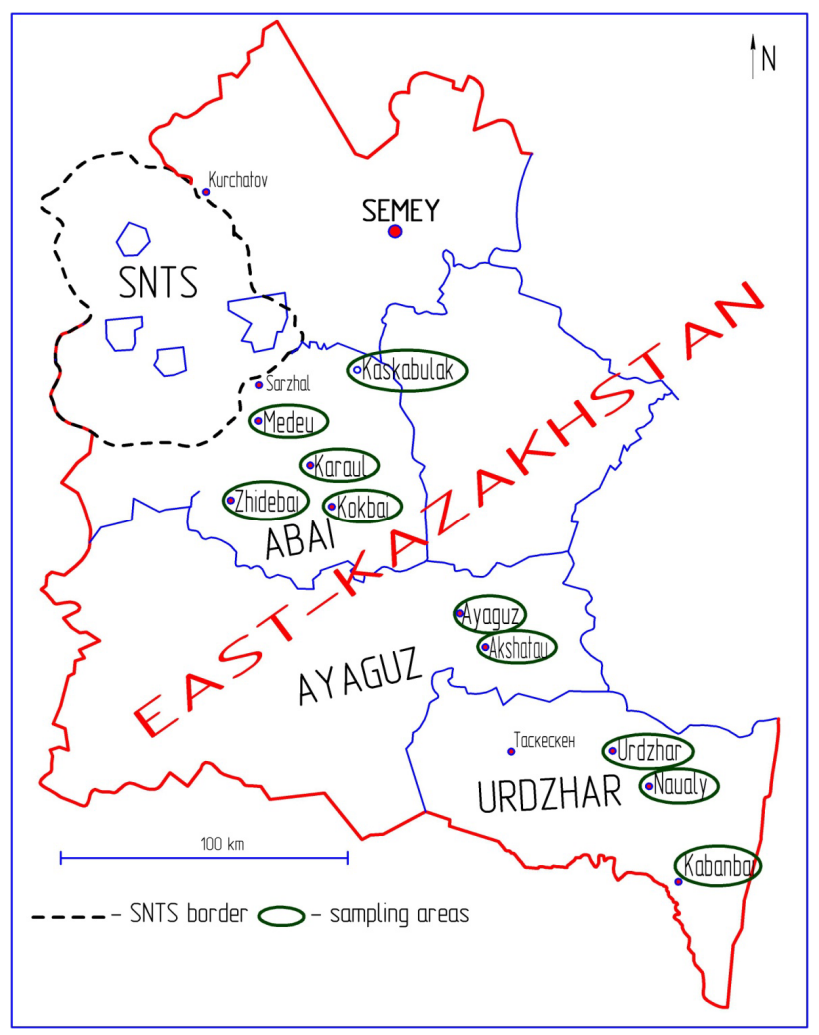

Figure 1. Sampling locations. stream with special polyethylene or metallic bucket. During the collecting water it is important to avoid troubled (muddy) places and places with strong sediments. Water samples were filtered and preserved with nitric acid ( $3 \mathrm{ml}$ per $1000 \mathrm{ml}$ of sample $(\mathrm{pH}<1))$. The $\mathrm{pH}$ was verified using an indicator paper. Samples were stored in a dark room with room temperature for 5 days. Then the radionuclides content were determined by the gamma-ray spectrometer using the Marinelly vessel.

Heavy metals $(\mathrm{Cd}, \mathrm{Pb}, \mathrm{Zn}, \mathrm{Cu})$ were identified and quantified using inductively coupled plasma mass spectrometry (ICP-MS) Varian-820 MS (Varian Company, Australia). Calibration standards Var-TS-MS, IV-ICPMS71A (Inorganic Ventures Company, USA) were used for calibrating the mass-spectrometer: sensitivity of the massspectrometer was tuned up using a diluted calibration solution Var-TS-MS with concentration of $\mathrm{Ba}, \mathrm{Be}, \mathrm{Ce}$, $\mathrm{Co}, \mathrm{B}, \mathrm{Pb}, \mathrm{Mg}, \mathrm{Tl}$, Th of $10 \mu \mathrm{g} / \mathrm{l}$. Three calibration solutions were used for the detector calibration. They were IV-ICPMS-71A of $\mathrm{Cd}, \mathrm{Pb}, \mathrm{Cu}$, Zn elements diluted to 10 , 50 and $100 \mu \mathrm{g} / \mathrm{l}$. Table 1 provides a list of the operating parameters of ICP-MS.

The samples of 1 - $2 \mathrm{~g}$ were combusted at the temperature of $400^{\circ} \mathrm{C}$ for 4 hours and then to $600^{\circ} \mathrm{C}$ for 2 hours in a muffle furnace. For the digestion of soil, vegetation and milk samples, a representative $1 \mathrm{~g}$ (dry weight) sample is digested with additions of $3 \mathrm{ml}$ nitric acid $\left(\mathrm{HNO}_{3}\right)$ and $2 \mathrm{ml}$ of $\mathrm{HF}$ in a microwave for $20 \mathrm{~min}$. After microwave digestion the samples were diluted with $1 \% \mathrm{HNO}_{3}$ in a $10 \mathrm{ml}$ vessel.

\section{Results}

The results of analysis of soil in Table 2 showed the different content of heavy metals by settlements. The highest content of Cd was measured in Ayaguz $0.11 \mathrm{mg} / \mathrm{kg}$, on the other hand, high value of $\mathrm{Pb}$ was measured in Urdzhar $19.7 \mathrm{mg} / \mathrm{kg}$. Soil collected from Naualy was most contaminated with $\mathrm{Zn} 17.3 \mathrm{mg} / \mathrm{kg}$ and $\mathrm{Cu}$ high value was measured in Kabanbai $0.21 \mathrm{mg} / \mathrm{kg}$. On the other hand, the lowest content of $\mathrm{Cd} 0.005 \mathrm{mg} / \mathrm{kg}$ was detected in Urdzhar, of $\mathrm{Pb} 1.8 \mathrm{mg} / \mathrm{kg}$ in Medeu, of Zn 1.1 $\mathrm{mg} / \mathrm{kg}$, of $\mathrm{Cu} 0.008 \mathrm{mg} / \mathrm{kg}$ in Kaskabulak. All measured data do not exceed the National limits of Cd $0.5 \mathrm{mg} / \mathrm{kg}$, $\mathrm{Pb} 32.0$ mg/kg, Zn $23.0 \mathrm{mg} / \mathrm{kg}$ and $\mathrm{Cu} 3.0 \mathrm{mg} / \mathrm{kg}$.

Table 1. Operating parameters of ICP.

\begin{tabular}{cc}
\hline Operating parameters & \\
\hline Plasma Flow (L/min) & 17.5 \\
Auxiliary Flow (L/min) & 1.70 \\
Sheath Gas (L/min) & 0.20 \\
Nebulizer Flow (L/min) & 1.00 \\
Sampling Depth (mm) & 6.5 \\
RF Power (kW) & 1.40 \\
Pump Rate (rpm) & 5 \\
Stabilization delay (s) & 10 \\
\hline
\end{tabular}


Table 2. Heavy metals concentration in soils, $\mathrm{mg} / \mathrm{kg}$.

\begin{tabular}{ccccc}
\hline Settlement & $\mathrm{Cd}$ & $\mathrm{Pb}$ & $\mathrm{Zn}$ & $\mathrm{Cu}$ \\
\hline Zhidebai & 0.072 & 6.4 & 5.3 & 0.07 \\
Karaul & 0.068 & 7.3 & 3.7 & 0.04 \\
Kokbai & 0.061 & 5.2 & 2.9 & 0.02 \\
Kaskabulak & 0.019 & 2.5 & 1.1 & 0.008 \\
Medeu & 0.095 & 1.8 & 6.8 & 0.11 \\
Akshatau & 0.089 & 5.6 & 2.1 & 0.01 \\
Ayaguz & 0.11 & 7.6 & 10.2 & 0.09 \\
Urdzhar & 0.005 & 19.7 & 13.9 & 0.13 \\
Naualy & 0.009 & 11.4 & 17.3 & 0.17 \\
Kabanbai & 0.006 & 8.9 & 15.4 & 0.21 \\
National limit & 0.5 & 32.0 & 23.0 & 3.0 \\
\hline
\end{tabular}

The results of the vegetation analysis (Table 3 ) showed the presence of high levels of Cd in Ayaguz $0.346 \mathrm{mg} / \mathrm{kg}$, which exceed the National limit $0.2 \mathrm{mg} / \mathrm{kg}$. Considerable quantity of $\mathrm{Pb} 1.96 \mathrm{mg} / \mathrm{kg}$, Zn $20.7 \mathrm{mg} / \mathrm{kg}$, Cu $11.1 \mathrm{mg} / \mathrm{kg}$ was measured in Naualy. The National limit for $\mathrm{Pb}, \mathrm{Zn}$ and $\mathrm{Cu}$ are $2.0 \mathrm{mg} / \mathrm{kg}, 50.0 \mathrm{mg} / \mathrm{kg}$ and $30.0 \mathrm{mg} / \mathrm{kg}$, respectively. The low levels of Cd were obtained in Urdzhar region (mean $0.079 \mathrm{mg} / \mathrm{kg}$ ) and in Kaskabulak of Abai region $0.045 \mathrm{mg} / \mathrm{kg}, \mathrm{Pb}$ in Medeu $0.09 \mathrm{mg} / \mathrm{kg}, \mathrm{Zn}$ in Akshatau $3 \mathrm{mg} / \mathrm{kg}$, of $\mathrm{Cu}$ in Kaskabulak $0.9 \mathrm{mg} / \mathrm{kg}$. According to the results of vegetation and soil analysis we can conclude that it was not observed the correlation of heavy metals in the vegetation concerning to the soil.

From Table 4 the level of $\mathrm{Cd} 0.009 \mathrm{mg} / \mathrm{dm}^{3}$ in water samples is approximately near to the maximum allowable limit of National limits in Ayaguz and Abai regions. In Urdzhar region $\mathrm{Pb}$ value of $0.039 \mathrm{mg} / \mathrm{dm}^{3}$ is a little higher than the National limit of $0.03 \mathrm{mg} / \mathrm{dm}^{3}$. Zn content in Naualy $1.5 \mathrm{mg} / \mathrm{dm}^{3}$, in Kabanbai $1.25 \mathrm{mg} / \mathrm{dm}^{3}$, in Urdzhar $1.05 \mathrm{mg} / \mathrm{dm}^{3}$ was found to exceed the National limit $1.0 \mathrm{mg} / \mathrm{dm}^{3}$. In Ayaguz Zn level $0.92 \mathrm{mg} / \mathrm{dm}^{3}$ was within the National limit. In all water samples the $\mathrm{Cu}$ content was not exceed the National limit. Contamination of water in these regions where the heavy metals was found to exceed the National limits is caused by the industrial plant waste.

The results of milk analysis (Table 5) indicated that in all samples of milk Cd level do not exceed the National limit $0.03 \mathrm{mg} / \mathrm{kg}$. The observed values showed the high mean of Cd are $0.027 \mathrm{mg} / \mathrm{kg}$ in Ayaguz and $0.021 \mathrm{mg} / \mathrm{kg}$ in Medey. The $\mathrm{Pb}$ content in 7 settlements of Urdzhar, Ayaguz and Abai regions exceed the National limit 0.1 $\mathrm{mg} / \mathrm{kg}$ : in Urdzhar $0.39 \mathrm{mg} / \mathrm{kg}$, in Naualy $0.24 \mathrm{mg} / \mathrm{kg}$, in Kabanbai $0.18 \mathrm{mg} / \mathrm{kg}$, in Ayaguz $0.15 \mathrm{mg} / \mathrm{kg}$, in Akshatau $0.11 \mathrm{mg} / \mathrm{kg}$, in Karaul $0.13 \mathrm{mg} / \mathrm{kg}$, in Zhidebai $0.12 \mathrm{mg} / \mathrm{kg}$. Zn concentration was found to exceed the National limit $5 \mathrm{mg} / \mathrm{kg}$ in Kabanbai $6.3 \mathrm{mg} / \mathrm{kg}$, in Naualy $5.8 \mathrm{mg} / \mathrm{kg}$. Approximate mean to the National limit was measured In Urdzhar $4.9 \mathrm{mg} / \mathrm{kg}$. Cu concentrations in observed settlements do not exceed the National limit 1.0
Table 3. Heavy metals concentration in vegetation, $\mathrm{mg} / \mathrm{kg}$.

\begin{tabular}{ccccc}
\hline Settlement & $\mathrm{Cd}$ & $\mathrm{Pb}$ & $\mathrm{Zn}$ & $\mathrm{Cu}$ \\
\hline Zhidebai & 0.219 & 0.99 & 6.8 & 3.5 \\
Karaul & 0.198 & 1.07 & 5.4 & 4.3 \\
Kokbai & 0.169 & 0.82 & 4.3 & 1.8 \\
Kaskabulak & 0.045 & 0.14 & 2.1 & 0.9 \\
Medeu & 0.311 & 0.09 & 9.3 & 4.9 \\
Akshatau & 0.294 & 0.57 & 3.0 & 1.3 \\
Ayaguz & 0.346 & 1.24 & 15.1 & 6.9 \\
Urdzhar & 0.064 & 1.89 & 17.0 & 8.1 \\
Naualy & 0.092 & 1.96 & 20.7 & 11.1 \\
Kabanbai & 0.082 & 1.56 & 18.3 & 9.5 \\
National limit & 0.2 & 2.0 & 50.0 & 30.0 \\
\hline
\end{tabular}

Table 4. Heavy metals concentration in water, $\mathrm{mg} / \mathrm{kg}$.

\begin{tabular}{ccccc}
\hline Settlement & $\mathrm{Cd}$ & $\mathrm{Pb}$ & $\mathrm{Zn}$ & $\mathrm{Cu}$ \\
\hline Zhidebai & 0.009 & 0.009 & 0.62 & 0.025 \\
Karaul & 0.007 & 0.011 & 0.45 & 0.014 \\
Kokbai & 0.007 & 0.003 & 0.32 & 0.009 \\
Kaskabulak & 0.003 & 0.001 & 0.12 & 0 \\
Medeu & 0.009 & 0.001 & 0.78 & 0.044 \\
Akshatau & 0.008 & 0.005 & 0.24 & 0.002 \\
Ayaguz & 0.009 & 0.015 & 0.92 & 0.031 \\
Urdzhar & 0.001 & 0.039 & 1.05 & 0.059 \\
Naualy & 0.004 & 0.028 & 1.5 & 0.071 \\
Kabanbai & 0.001 & 0.027 & 1.25 & 0.082 \\
National limit & 0.01 & 0.03 & 1.0 & 0.1 \\
\hline
\end{tabular}

Table 5. Heavy metals concentration in milk, mg/kg.

\begin{tabular}{ccccc}
\hline Settlement & $\mathrm{Cd}$ & $\mathrm{Pb}$ & $\mathrm{Zn}$ & $\mathrm{Cu}$ \\
\hline Zhidebai & 0.011 & 0.12 & 2.3 & 0.18 \\
Karaul & 0.009 & 0.13 & 1.9 & 0.13 \\
Kokbai & 0.007 & 0.054 & 1.4 & 0.09 \\
Kaskabulak & 0.001 & 0.012 & 0.3 & 0.01 \\
Medeu & 0.021 & 0.09 & 3.7 & 0.22 \\
Akshatau & 0.017 & 0.11 & 0.9 & 0.06 \\
Ayaguz & 0.027 & 0.15 & 4.1 & 0.28 \\
Urdzhar & 0.003 & 0.39 & 4.9 & 0.41 \\
Naualy & 0.008 & 0.24 & 5.8 & 0.7 \\
Kabanbai & 0.006 & 0.18 & 6.3 & 0.54 \\
National limit & 0.03 & 0.1 & 5.0 & 1.0 \\
\hline
\end{tabular}

$\mathrm{mg} / \mathrm{kg}$, but the high value was measured in Naualy 0.7 $\mathrm{mg} / \mathrm{kg}$. According to the milk analysis $\mathrm{Pb}$ and $\mathrm{Zn}$ heavy metals were found to exceed the National limit.

\section{Discussion}

From the data presented above, studied regions were mostly contaminated with Zh which exceeded the National limit in water in Naualy, Kabanbai, Urdzhar, in milk samples in Naualy and Kabanbai, and in vegetation $\mathrm{Cd}$ exceed in Auyaguz. The mean level of $\mathrm{Pb}$ was up of the National limits in milk of Urdzhar region, Ayaguz region and Abai region (Karaul, Zhidebai settlements). 
Cd concentrations were found to exceed the National limit in the vegetation of Ayaguz, Medeu, Akshatau and Zhidebai settlements. Cu measured levels were not found to exceed the National limit.

This study assesses the vulnerability of ecological system and therefore food safety. Future studies will intend to increase both the quality and the quantity of milk by decreasing heavy metal content there.

\section{REFERENCES}

[1] S. M. Sabir, S. W. Khan and I. Hayat, "Effect of Environmental Pollution on Quality of Meat in District Bagh, Azad Kashmir,” Pakistan Journal of Nutrition, Vol. 2, No. 2, 2003, pp. 98-101. http://dx.doi.org/10.3923/pjn.2003.98.101

[2] C. Hura, N. Munteanu and V. Stoleru, "Heavy Metals Levels in Soil and Vegetables in Different Growing Systems,” E3S Web of Conferences 1, 08007, 2013.
[3] B. Aslam, I. Javed, F. H. Khan and Z. U. Rahman, “Uptake of Heavy Metal Residues from Sewerage Sludge in the Milk of Goat and Cattle during Summer Season," Pakistan Veterinary Journal, Vol. 31, No. 1, 2011, pp. 75-77.

[4] T. M. Carlsen, L. E. Peterson, B. A. Ulsh, C. A. Werner, K. L. Purvis and A. C. Sharber, "Radionuclide Contamination at Kazakhstan Semipalatinsk Test Site: Implications on Human and Ecological Health,” US Department of Energy, UCRL-JC-143920, 2001.

[5] F. Damian and G. Damian, "Detoxification of Heavy Metal Contaminated Soils," American Journal of Environmental Sciences, Vol. 3, No. 4, 2007, pp. 193-198. http://dx.doi.org/10.3844/ajessp.2007.193.198

[6] N. I. Ward and J. M. Savage, "Metal Dispersion and Transportational Activities Using Food Crops as Biomonitors," Science of the Total Environment, Vol. 146, 1994, pp. 309-319.

http://dx.doi.org/10.1016/0048-9697(94)90251-8 